Journal of English Language Teaching and Applied Linguistics

ISSN: 2707-756X

DOI: $10.32996 /$ jeltal

Journal Homepage: www.al-kindipublisher.com/index.php/jeltal

\title{
The Online Learning Strategies: A Case Study On English Teachers in East Nusa Tenggara Province-Indonesia
}

\author{
Gracia M. N. Otta \\ Lecturer of English Study Program, Nusa Cendana Nusa Cendana University, East Nusa Tenggara, Indonesia \\ $\square$ Corresponding Author: Gracia M. N. Otta, E-mail: gracia.otta.staf.undana@ac.id
}

\begin{abstract}
ARTICLE INFORMATION ABSTRACT
Received: 01 September 2021

Accepted: 25 October 2021

Published: 26 October 2021

DOI: 10.32996/jeltal.2021.3.11.5

\section{KEYWORDS}

Learning from home, Online learning, Offline learning, Applications, Strategies.

During the covid 19 pandemic, online learning, and its terms are not strange things in East Nusa Tenggara. The establishment of Learning from home was started from March to June 2020 to prevent the spread of Covid-19. This research is a case study of eleven English teachers who serve in certain areas around East Nusa Tenggara; five teachers of Senior High School/Vocational School, five teachers of Junior High School, and one Elementary School teacher. Its purpose was to describe the methods in the English teaching-learning process in a pandemic situation. The data of this descriptive study were obtained through WhatsApp non-facial interviews and analyzed by reducing and categorizing similar results. The results showed that the teachers applied two methods, both offline and online. From March to June 2020, the teachers managed their classes in the online process by using some applications. Whereas, in the Uneven Semester 2020-2021, the safe areas return to face-to-face learning in limited learning duration. The most prominent obstacle in online learning was the limitation of gadgets since the students did not have adequate tools. Financially, parents' income has decreased for they could not meet the needs of internet data packages. Students who returned to their hometown also experienced problems regarding network services. These conditions cause more obstacles to teachers in managing online classes. Therefore, teachers implemented several strategies to solve these obstacles by creating a WhatsApp group or arranging them into small groups based on their locations and there were students with smartphones to browse for materials or send the assignments. In addition, students were allowed to consult and collect the assignments at school based on scheduled agreements. The situation continues to Even Semester 2020-2021 and gradually turned to limited face-to-face meetings at school in the Uneven Semester 2021-2022.
\end{abstract}

\section{Introduction}

Recently the world was shocked by the Covid-19 outbreak. The pandemic has gradually affected several aspects of social life. Almost all activities are organized online. People were prohibited from doing face-to-face activities regarding the break of virus spread.

Cultural shifts are slowly taking place. It encompasses the concepts of education in the world, as well as Indonesia, which previously the teaching-learning activities was completed traditionally in the classroom, regularly, and managed face-to-face. Lately, it was arranged using several social networking applications in virtual teaching-learning activities.

In the pandemic situation, Ministry the Indonesian Ministry of Education of Culture released Administrative Circular letters related to the spread of Covid-19. First, The Circular Letters Number 2 of 2020, concerning the Prevention and Handling of Covid-19 within the Ministry of Education and Culture. Second, The Circular Letters Number 3 of 2020, concerning Prevention of Covid-19 in the Education Unit. Third, Circular Letters Number 4 of 2020, concerning the Implementation of Education Policies in an Emergency

Copyright: (c) 2021 the Author(s). This article is an open access article distributed under the terms and conditions of the Creative Commons Attribution (CC-BY) 4.0 license (https://creativecommons.org/licenses/by/4.0/). Published by Al-Kindi Centre for Research and Development, London, United Kingdom. 
for the spread of Covid-19 which includes specific instructions on the learning process from home. Fourth, The Circular letters of the Secretary-General of the Indonesian Ministry of Education and Culture Number 15 of 2020 presented Guidelines for Organizing Learning from Home in a Pandemic Period. Undeniably, the distance learning process required the participation and involvement of students, teachers, also parents.

These policies described the limitation of social interaction between teachers and students. Various regions in Indonesia have established learning from home policies, including East Nusa Tenggara Province. Distance learning was implemented to support these issues. The purpose of this research is to examine the strategies and solutions for coordinating learning from home policy. Online learning is a system of managing virtual face-to-face teaching and learning activities directly between teachers and students using the internet network. Educators must guarantee those teaching-learning activities, examinations, and evaluations can survive even though students are at home. These processes insisted the educator's design innovative even without face-to-face meetings.

For some educational institutions that are familiar with online lectures, the format of online teaching-learning using internet-based is not a problem. Teachers or lecturers only need to increase and change face-to-face sessions into virtual meetings through the internet. On the other hand, other education institutions that are unfamiliar with this experienced stuttering and bring new obstacles. For they have to adapt lightning fast to conduct online teaching-learning.

The essence of virtual education is the successful learning outcomes based on the methods and tools used in online teachinglearning. Various learning applications are also attempted to support the activities. Some applications used are Zoom Cloud Meeting, Google Classroom, Google Meet, WhatsApp, Facebook Messenger, Cisco Webex Meeting, and others. It results in new terms and those applications suddenly become popular and familiar among teachers, lecturers, and students. However, the delivery of these teaching-learning materials forces educators to be more creative and the most important thing is to adjust the situations and conditions of the place they serve.

Challenges seem to appear during online teaching-learning activities. This cannot be separated from the teachers who serve in several parts of East Nusa Tenggara Province. Efforts were made to face the obstacles. This research contains various matters related to online teaching-learning, its strategies, and solutions applied by the teachers.

\section{Supporting Theories}

The realization of learning from home guidelines in the Circular Letters also regulated the learning system, learning materials, learning resources. It emphasizes the standardization of teaching-learning services received by the students equally.

A study in Peking University stated five high-principles for online educations; (1) correlation between online instructional design and student learning, (2) understandable information delivery, (3) supported and assisted by faculty, (4) high-quality participation to improve teaching-learning activities, (5) anticipating plans and unexpected incidents of the online education platforms (Bao, 2020).

Ragan (2009) stated Ten Principles of Effective Online Teaching: Best Practices in Distance Education based on his faculty faced by having online education. Those are (1) Show Up and Teach, (2) Practice Proactive Course Management Strategies, (3) Establish Patterns of Course Activities, (4) Plan for the Unplanned, (5) Response Requested and Expected, (6) Think Before You Write, (7) Help Maintain Forward Progress, (8) Safe and Secure, (9) Quality Counts, and (10) (Double) Click a Mile on My Connection. They play an important role in managing online teaching-learning. Students rely on teachers' strategies in teaching and in using Learning Management System in order to track students' works. At that moment, the online activities benefit both teachers and students.

Few countries are monitoring the effective reach and use of distance learning modalities. However, estimates indicate variable coverage: distance learning in high-income countries covers about 80-85 percent, while this drops to less than 50 percent in lowincome countries. This shortfall can largely be attributed to the digital divide, with the disadvantaged having limited access to basic household services such as electricity; a lack of technology infrastructure, and low levels of digital literacy among students, parents, and teachers (UN Policy Brief- Covid-19 and Education - August 2020, n.d.)

The implementation of online learning in East Nusa Tenggara is not as simple as imagined. Constraints arise in some areas with limited internet access, means of communication, and distance of students' residence. This is supported by research done by (Satrianingrum \& Prasetyo, 2020) who revealed difficulties faced by teachers in organizing online teaching-learning. It showed several obstacles related to inadequate facilities and infrastructures, the burden of internet quota, network connections, and the lack of flexibility in controlling students' activities.

It is clear that strategies are important in organizing online teaching-learning. Besides, parents and students must be active. Collaborative learning with peers is one of the strategies to increase students' interest in completing the assignments given. It 
includes the combination of collaborative activities, reflective activities, clear assessment criteria, and integration of technology (Niess \& Gillow-Wiles, 2013) Nevertheless, to support online learning, whether conducted individually or collaboratively, teachers students and parents must possess the ability to operate technology. Also, another teaching problem during the Covid-19 pandemic was the teachers' disability in accessing technology, school facilities in supporting e-learning, the difficulties in explaining the materials, students' limitation in accessing the internet, students' economic background, and the support from parents (Lestiyanawati \& Widyantoro, 2020).

Several contributors in the education field stated some strategies that might be useful in conducting teaching-learning. It was reported by (Gallagher, 2020) in A Report of USC Rossier School of Education. A misconception is that teachers need to engage students in online instruction for the same duration as a regular school day. This can lead them to stay for many hours in front of electronic devices. It is better to avoid making online instruction feel like hours of busy work. (Mora-Flores, 2020). Furthermore, recommendations for educators include (1) offering video conference meetings, (2) creating a community rather than just a classroom to build students' social-emotional, (3) Use a portion of class time to allow students to share personal updates, (4) creating a video or exploring tasks, (5) plenty opportunities for young learners to take a break and keep them learning through educational games.

Among all these strategies, the simplest medium for delivering teaching materials in East Nusa Tenggara is through a message application that is easy to operate by teachers, parents, and students called WhatsApp. It is an application to send instant messages both individually or in groups (texts, pictures, videos, or voice messages). Besides, it also provides features to dial phone numbers and to have a conference call. (Preston et al., 2010) found that nearly $70 \%$ of students state how learning activities can be completed well in online learning communities such as WhatsApp groups, Facebook communities, Twitter chats, and Google+ communities, as they do in lectures that are held in the classroom in the presence of other students.

In addition, to have achievements through online learning, students themselves as the individual must have self-motivation and be pro-active in this process. The ability to master technology is no less important in finishing these online activities.

\section{Methods}

\subsection{Types of Research}

In completing this case study, the writer applied the qualitative research method. It describes as a method without statistical calculations which related to a person's life, stories, behaviors, organizational functions, social movements, or reciprocal relationships. (Creswell, 2014) defined qualitative research as an approach for exploring and understanding the meaning individuals or groups ascribe to a social or human problem.

Qualitative inquirers use theory in their studies in several ways. First, much like in quantitative research, it is used as a broad explanation for behavior and attitudes, and it may be complete with variables, constructs, and hypotheses. Second, researchers increasingly use a theoretical lens or perspective in qualitative research, which provides an overall orienting lens for the study of questions of gender, class, and race (or other issues of marginalized groups). Third, distinct from this theoretical orientation are qualitative studies in which theory (or some other broad explanation) becomes the endpoint. Fourth and finally, some qualitative studies do not employ any explicit theory (Creswell, 2014).

A case study may be understood as the intensive study of a single case where the purpose of that study is - at least in part - to shed light on a larger class of cases (a population). Case study research may incorporate several cases, that is, multiple case studies (Gerring, 2006). Therefore, this case study research explains the phenomenon of online teaching-learning especially the strategies applied by English teachers to complete teaching objectives.

\subsection{Data Collection Techniques and Instruments}

The qualitative interview method is a technique for collecting data and information. It also connects the researchers and research subjects. It uses flexible questions guideline to collect the data from the informants.

In order to collect the data, the non-facial interview was applied (Mahsun, 2005). It is an act of asking and answering questions through electronic devices such as social media, or other message service applications. The writer used WhatsApp Messenger to communicate and conduct the non-facial interview. It was completed in October 2020. She investigated some obstacles encountered and strategies used by English teachers in several areas in East Nusa Tenggara to conquer difficulties in implementing online teaching-learning in a pandemic situation.

The type of non-facial interview that applied in this research is a structured interview where the writer determined the problems herself in the form of questions. Questions were arranged based on teachers' experiences, behaviors, and actions which can be described. (Guba \& Lincoln, 1981), (Patton, 1978), (Moleong, 2015). 
Questions were formulated based on five basic points; (1) teaching location, (2) teaching level (primary or secondary), (3) teaching methods in pandemic situations, (4) online teaching obstacles, (5) strategies and solutions.

\subsection{Source of Research}

The subjects of this research consisted of eleven English teachers; five High School teachers (two of them teach in Vocational School), five Junior High School teachers, and one Elementary School teacher.

The locations for High School teachers are in Sikka Regency, Rote Ndao Regency, Alor Regency, Sabu Raijua Regency, and Kupang Town. Junior High School locations are in Malaka Regency, Rote Ndao Regency, Lembata Regency, and Kupang Town. While for Elementary School, it is located in Kupang Town.

The teachers graduated from English Study Program; nine of them are Graduate level and two of them are Post-Graduate level.

\subsection{Data Analysis}

In general, the data analysis process used is Grounded Research or Constant Comparative Method by comparing theories (Glaser \& Strauss, 2009), (Moleong, 2015). In analyzing the data, the writer was concerned about the use of the data reduction process by identifying units that related to the research problems. Afterward, she categorized them by sorting each unit into parts that have a similarity.

\section{Findings and Discussion}

The data were categorized into several sections. The first is based on the level of teaching, whether in the primary or secondary level. Second, it is based on the most common method applied in teaching-learning activities that included the applications. The third is to identify obstacles faced by the teachers in the teaching-learning process, and the last is to explain strategies used by teachers in running teaching-learning activities.

The first informant is a High School Teacher in Sikka Regency. In completing online teaching-learning, the teacher herself created a WhatsApp group for every class. It consists of the teacher and students. She shared important materials through that group or Google Classroom. Students can submit their assignments, quizzes, or tests to those applications and also allow them to send emails.

Second is a teacher of a Senior High School in Alor Regency. In order to control the students' learning process, she applied both offline and online methods. To prevent virus spread and to obey the health protocols, she created small groups learning.

The third informant is a Vocational High School in Rote Ndao Regency. She organized both offline and online methods in teaching English. She also created small groups in several places.

Fourth is also a Vocational High School Teacher from Sabu Raijua Regency. From March to June 2020, she taught English in an online method through WhatsApp and Facebook Messenger. Considering the Regency is safe for face-to-face learning in the Uneven Semester 2020-2021, they manage the teaching-learning process in school.

The fifth informant is a Private High School teacher in Kupang Town. Since it is unable to arrange face-to-face meetings in school, she applied online learning by using two applications; Zoom Cloud Meeting and Google Classroom.

Sixth is a private Senior High School teacher in Malaka Regency. They have run the online method from March to June 2020. In the Uneven Semester 2020-2021, they arrange a short school meeting since the regency was safe to do the offline method.

Next, the seventh informant is an English teacher in Rote Ndao Regency. She needed to manage offline teaching learning because they could not deal with the online method.

Similar to the seventh informant, this English Teacher of a Private Junior High School in Kupang town also carried out classes in offline method. She taught small classes then it was easy for them to create small groups in some places around students' locations. Different from the previous informant, a teacher of another Private Junior High School in Kupang town manage his class by having online activities through WhatsApp group. He created his classes groups in order to be easier in managing the class instructions.

The tenth informant comes from Lembata Regency. He is an English Teacher of a Junior High School. he combined both online and offline methods in teaching. 
The last one is an Elementary English teacher from Kupang Town. She also organized her classes both in online and offline methods.

Based on the methods operated by eleven English teachers, both online and offline, the writer argued that they tried to attempt simple and easy means to complete the lessons. Yet, at the same time, they must consider students' finances and location in connection with internet access. For the green zone, it was quite undemanding to have short meetings. While in the red zone, teachers, students, and parents were required to collaborate, considering learning English without practicing will not be complete.

The writer divides obstacles revealed by the English teacher into some sections. Teachers' statements were clearly indicated obstacles arose in having online teaching-learning. The most obvious was most students personally did not have their own smartphones. They used their parents' phones. Students' needed to wait for their working parents to come home then they could access the assignments.

Apart from that, students preferred to return to their hometown during the pandemic. It caused another problem, where the network condition was inadequate which resulted in them having difficulties in getting information about school projects. Teachers then admitted that assignments could not be submitted at the same time. Undeniably, teachers faced difficulties in monitoring students' attendance during school hours.

Furthermore, it is explained that financially, students experienced crisis since their parents were unable to earn more income which hard for them to always purchase the credits. Another important part, teachers revealed that learning English skills required sufficient space and time to practice, whether in listening, speaking, reading, writing, or learning grammar. Therefore, students themselves also must be responsible for what they learned.

In solving the problems in teaching-learning from home, both offline and online, teachers had their own strategies. The writer categorized them into two parts; offline and online. To fulfill offline teaching-learning from home, teachers and students collaborated in creating learning groups. They also agreed on learning schedules. Every group created consists of five to six students who live in certain areas and there are students with smartphones so they can send assignments after having classes. To make it easier, assignments can be collected to school according to the agreements among teachers and students.

For more strategies, due to homework matters, teachers limited the amount. If students met difficulties in learning, they could consult through WhatsApp or emails. It can be said that offline method students had opportunities to practice English skills directly. But, the limitations of time are still an obstacle. Students are required to find other learning media to develop their English skills.

Whereas for the online method, teaching-learning activities were completed by using some applications that can be easily accessed by students; WhatsApp, Facebook Messenger, Google Classroom, and email. For virtual meetings, they used the Zoom Cloud Meeting application. Several schools have also increased online learning facilities. Students received internet packages.

Undeniably, learning from home is challenging. One more important thing would be communication with students' parents to monitor the learning process from home. However, the English teachers have done their best to overcome obstacles. Gradually, the situation was getting better. In the Uneven Semester 2021-2022, schools were opened and allowed to have limited face-toface meetings at schools.

\section{Conclusion and Suggestions}

Implementing learning from home is not an easy process. It is challenges teachers, students, also parents in managing precise methods. Even in Kupang Town, East Nusa Tenggara Province's capital, and in several areas in east Nusa Tenggara Regencies, still encounter problems. Teachers and students experienced geographical constraints due to the distance of students' residence, the facilities of the communication network, the availability of gadgets, and the ability to fulfill internet data packages. To overcome this, the strategy used for those in the Kupang Town, two teachers continued to do online through WhatsApp Group, Google Classroom, e-mail, and Zoom Cloud Meeting. Three teachers organized the full offline method because online learning was too difficult, at the same time they were in the green zone where this activity was possible to be managed. While, the most implemented were blended learning in form of WhatsApp Group, Google Classroom, and visitation to a small group of students in their residences.

It is expected that this research is useful as worthwhile information for the readers who decide to use it as a guideline or additional literature in relation to strategies applied by teachers in online teaching-learning. For other researchers who intend to conduct researches in the same field may broaden and enlarge different subjects of research to achieve the maximum result. This research is mainly intended to describe various strategies applied by English teachers to teach English in the pandemic situation and encourage students that they still can learn English even though in difficult circumstances. 
Acknowledgements: This research was supported by eleven incredible English teachers who were willing to share their teachinglearning experiences in the pandemic situation and also for some important people who always present their genuine assistances along this research process. Despite the difficulties these days, teaching is also learning at the same time. Therefore, the writer would like to express her sincere gratitude and appreciation.

\section{References}

[1] Bao, W. (2020). COVID -19 and online teaching in higher education: A case study of Peking University. Human Behavior and Emerging Technologies, 2(2), 113-115. https://doi.org/10.1002/hbe2.191

[2] Creswell, J. W. (2014). Research design: Qualitative, quantitative, and mixed methods approach (4th ed). SAGE Publications.

[3] Gallagher, K. S. (2020). Supporting Online Learning in A Time of Pandemic.

[4] Glaser, B. G., \& Strauss, A. L. (2009). The discovery of grounded theory: Strategies for qualitative research (4. paperback printing). Aldine.

[5] Guba, E. G., \& Lincoln, Y. S. (1981). Effective evaluation (1st ed). Jossey-Bass Publishers.

[6] Lestiyanawati, R., \& Widyantoro, A. (2020). Strategies and Problems Faced by Indonesian Teachers in Conducting E-Learning System During COVID-19 Outbreak. 1, 12.

[7] Mahsun. (2005). Metode Penelitian Bahasa: Tahapan Strategi, Metode, dan Tekniknya (2005th ed.). Raja Grafindo Presada.

[8] Moleong, L., J. (2015). Metodologi Penelitian Kualitatif (2015th ed.). PT Remaja Rosdakarya.

[9] Niess, M., \& Gillow-Wiles, H. (2013). Developing Asynchronous Online Courses: Key Instructional Strategies in a Social Metacognitive Constructivist Learning Trajectory. 2013, 27(1), 1-23.

[10] Patton, M. Q. (1978). Qualitative Evaluation Methods. Sage Publisher.

[11] Preston, G., Phillips, R., Gosper, M., McNeill, M., \& Woo, K. (2010). Web-based lecture technologies: Highlighting the changing nature of teaching and learning. Australasian Journal of Educational Technology, 12.

[12] Ragan, L., C. (2009). 10 Principles of Effective Online Teaching: Best Practices in Distance Education. Magna Publication.

[13] Satrianingrum, A. P., \& Prasetyo, I. (2020). Persepsi Guru Dampak Pandemi Covid-19 terhadap Pelaksanaan Pembelajaran Daring di PAUD. Jurnal Obsesi: Jurnal Pendidikan Anak Usia Dini, 5(1), 633. https://doi.org/10.31004/obsesi.v5i1.574

[14] UN Policy Brief- Covid-19 and Education-August 2020. (n.d.).

[15] Suat Edaran Mendikbud No.2 Tahun 2020 tentang Pencegahan dan Penanganan Corona Virus Disease 2019 (Covid-19) di Kementerian Pendidikan dan Kebudayaan.

[16] Surat Edaran Mendikbud No.3 Tahun 2020 tentang Pencegahan Corona Virus Disease 2019 (Covid-19) pada Satuan Pendidikan

[17] Surat Edaran Mendikbud No.4 Tahun 2020 tentang Pelaksanaan Kebijakan Pendidikan dalam Masa Darurat Penyebaran Corona Virus Disease 2019 (Covid-19)

[18] Surat Edaran Sekretaris Jenderal Kementerian Pendidikan dan Kebudayaan No.15 Tahun 2020 Tentang Pedoman Penyelenggaraan Belajar dari Rumah dalam Masa Darurat Penyebaran Corona Virus Disease (Covid-19) 